\title{
Electric Moms and Quad Drivers: People with Disabilities Buying, Making, and Using Technology in Postwar America
}

\section{Bess Williamson}

In 1958, a young mother named Ida Brinkman reflected on her life after contracting polio. Five years had passed, she told the readers of the Toomeyville Junior Gazette - a magazine for polio survivors - since she had become paralyzed in her arms, legs, and abdomen. After a two-year stay at the Toomey Pavilion, a rehabilitation center in Ohio, she admitted she was "secretly frightened" about how her home life would be, using an iron lung at night, a "chest shell" respirator during the day, and a wheelchair to get around. " "This is beginning to sound pretty grim," she wrote, admitting concern about resuming her life as a wife and mother; still, she continued, it really hadn't been so bad. At home, her husband Johnny had taken up shopping duties, while her three children helped keep house and prepared their own breakfasts. A cartoon accompanying the article showed Ida in a wheelchair, a tube at the center of her chest connecting her to an electric respirator, as her little daughter gazed at her quizzically. "Bonnie gets acquainted with her Electric Mom," read the caption [Figure 1]. "To my glee," Ida reported, "she accepted me."2

Ida Brinkman's life as an "Electric Mom" extended beyond the plug-in chest respirator that drew her chest muscles up and down. She ticked off a number of tools she and her husband selected and, in many cases, altered to support a busy and active life at home. Johnny constructed a flat aluminum connector for the hose of her respirator, making the breathing apparatus less bulky. The electric Hoyer lift that Ida used to get into and out of bed included "a new wrinkle added 


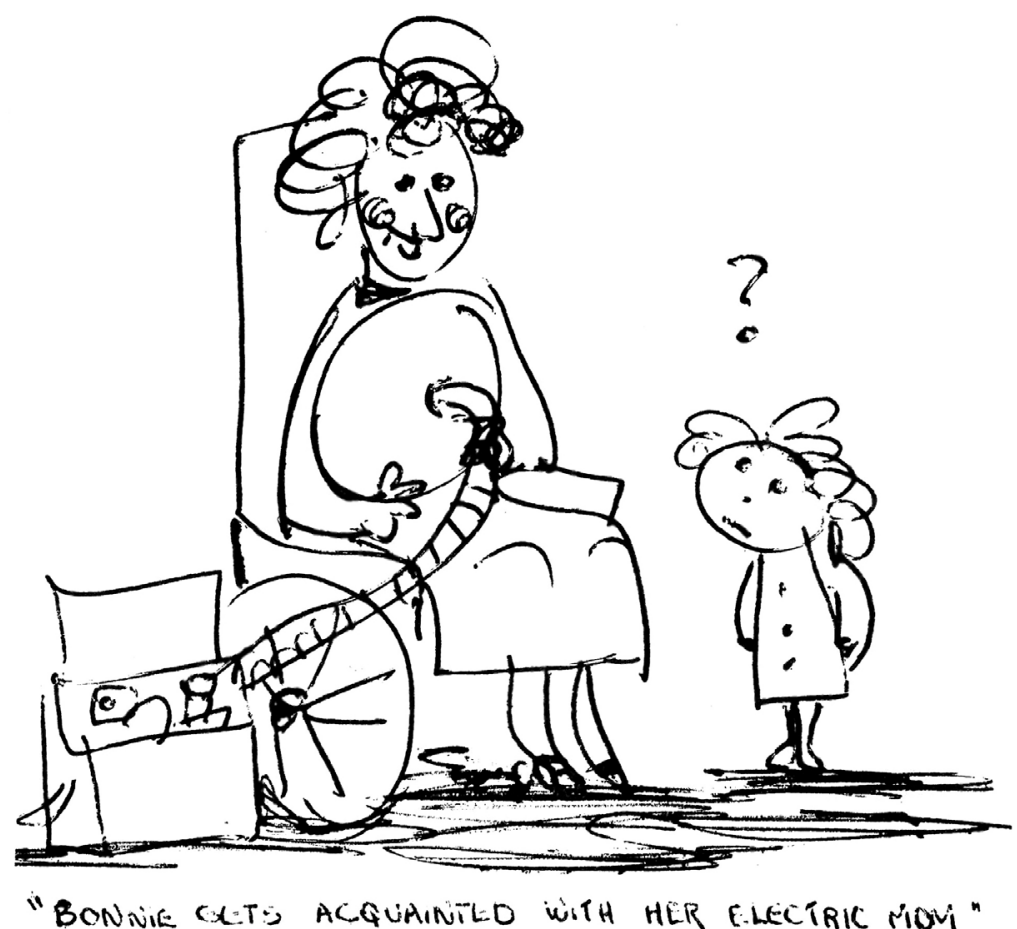

Figure 1: "Bonnie gets acquainted with her Electric Mom," Toomeyville Junior Gazette, Winter 1958, 13. Courtesy of Post-Polio Health International.

to it ala hubby [sic]": a shorter hook that could be used to help her into the car, effectively making two lifts out of one. Ida's father built a portable wooden ramp that was "especially practical for steep declines"; she used an extended cord and headset for the telephone; and, in case of "urgent s.o.s." while alone with her children, she had an "alarm box which can be set off by a flick of a foot." In a photograph in a later issue of the Toomey J Gazette (as the magazine came to be known), Ida appeared propped up in bed, reaching past the customized respirator tube to type with a "mouthstick" - probably a simple dowel with a sharpened tip_-clenched between her teeth [Figure 2]. ${ }^{4}$ Surrounded by her collection of medical, homemade, and standard consumer technologies - the chest shell and "mouthstick," the hospital bed, an over-the-bed desk, and the typewriter-Ida showed herself in action as a writer and editor.

Ida Brinkman was one of a growing number of people with significant physical impairments who lived at home in mid-century America. ${ }^{5}$ Given innovations such as the "iron lung" respirator and advancements in spinal surgery, people who 


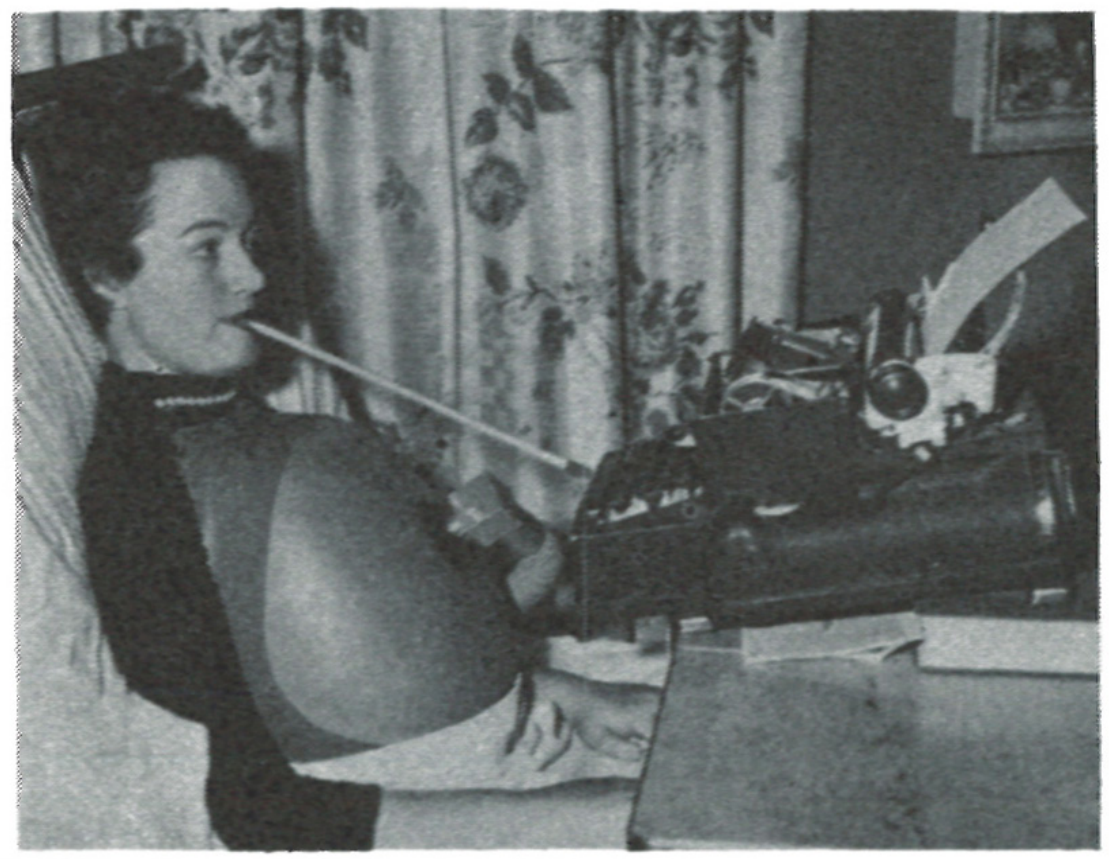

Figure 2: Horizontal Editor Ida, from "Happy Birthday," Toomey J Gazette, Fall-Winter 1959, 8. Courtesy of Post-Polio Health International.

survived disabling diseases and accidents were more likely to live long, relatively healthy lives after the 1940s. The new medical specialty of "rehabilitation" emphasized a return to home, rather than long periods of convalescence, as the end goal of treatment. Despite these improved prospects, however, individuals with paralysis, missing limbs, weakened joints or restricted breathing left the hospital for home lives full of physical obstacles. Accommodations now familiar in the United States, such as wheelchair ramps, automatic doors, accessible toilets, and "kneeling" public buses were not widely extant until the late 1970s and 1980s. ${ }^{6}$ The American National Standards Institute published "Specifications for Making Buildings and Facilities Accessible to and Usable by Handicapped People" in 1961. While these standards were officially adopted for new construction in many states and municipalities, few accessible buildings and streetscapes were actually built in the 1960s. Features such as curb cuts, wheelchair ramps to public buildings, and accessible restrooms were not common sights in American cities until the mid-1970s, and in many locales were not widespread until new federal regulations were adopted in 1977 , following nationwide protests by disability rights groups. Before that period, people with disabilities could expect minimal assistance in navigating public spaces, let alone the built-in obstacles of the postwar home. 
In the Toomey J Gazette, Ida Brinkman and dozens of other people with disabilities documented their work as tinkerers, taking a "do-it-yourself" approach to available consumer and technological products. Adapting specialized medical and assistive equipment, altering their own houses and everyday household tools, and using forms of transportation - especially customized automobiles - to move beyond the home, these individuals used technology to fill a gap left by postwar medical treatment of disability. ${ }^{7}$ The growing rehabilitation movement in American medicine presented an optimistic view of disability, trumpeting the individual's ability to "overcome" given proper care and training. The message that new specialists delivered was equal parts encouragement and pressure, particularly when it came to physical mobility and access. Prodding people with even severe paralysis to learn to walk, eat, and care for themselves without outside assistance, specialists found the solution to accessibility in individual effort, not physical accommodation. ${ }^{8}$ For people with disabilities and their families, technological tinkering could alleviate some of the burden of everyday access.

People with disabilities documented their technological experiments in community periodicals of the time and in retrospective memoirs and oral histories. The Toomey $J$ Gazette provides a remarkable source of first-person accounts of technological adaptation in the 1950s and 1960s. The sometimes-annual, sometimes-quarterly magazine began with 125 mimeographed copies compiled by "three horizontal and two vertical editors"- three women paralyzed by polio and two volunteers they had met undergoing rehabilitation at the Toomey Pavilion (one of whom, Gini Laurie, remained at the editorial helm throughout the magazine's run). ${ }^{9}$ Circulation grew to 2,000 in one year and exceeded 10,000 by $1967 .{ }^{10}$ The Gazette focused with great detail on the logistics of everyday life for those with significant physical impairments. The editors defined their audience as primarily "respos," or those who had had respiratory cases of polio, but eventually included people with spinal cord injuries and other "quads" and "paras," medical shorthand for quadriplegics and paraplegics. As many as threequarters of the articles in a given issue addressed technological issues, from user reports on assistive devices in the regular "Equipment" column, to an eclectic mix of do-it-yourself and imagined products under the headings of "Oddments and Endments" and "Brainstorms."

Although this publication provides the most extensive store of amateur technological reports, other periodicals targeted towards physically disabled readers also addressed these activities. In the Paralyzed Veterans of America's Paraplegia News, which began publication in 1951, a different population shared suggestions on such things as new automatic and remote-control appliances, preferred commercial and homemade solutions for wheelchair ramps, and customized, hand-controlled cars. ${ }^{11}$ Personal documents and oral histories gathered from the generation who survived the peak epidemic of polio fill out the picture of a population who managed daily activities through technological adaptation. ${ }^{12}$

These accounts reflect the demographics of people with disabilities who were able to live at home, create their own forms of access, and share them through 
community publications during this era. The polio survivors and veterans featured in the Toomey J Gazette and Paraplegia News represented two small slices of the population of people with disabilities who garnered disproportionate public attention and resources. In the years following World War II, the U.S. government funneled significant resources into helping disabled veterans transition into civilian life, promising that they, like their non-disabled fellow service-members, would share in the prosperity of postwar life. ${ }^{13}$ Likewise, during and after the peak polio epidemic of 1937-1955 — a period when more than 415,000 cases of the mysterious and terrifying virus were reported (declining only after Jonas Salk's discovery of a vaccine) - polio became central to a new public discourse on charity and public health. ${ }^{14}$ In the 1940s and 1950s, organizations such as the National Foundation for Infantile Paralysis (NFIP, also known as the March of Dimes) launched campaigns including mailings, advertisements, television shows, and public events, cementing disability — and specifically polio — as a key target for private philanthropy. ${ }^{15}$

In addition to these attributes of relative privilege among the disabled population, the writers for disability-community periodicals narrated a version of adaptation within the relatively limited arena of middle-class, largely white America. In the twelve-year run of the Gazette, there were only three photographs of identifiably non-white Americans: two of them, of apparently African American men, appeared in an article about activities at a residential institution, reflecting the disproportionate representation of poor and nonwhite persons among the institutionalized population. ${ }^{16}$ The majority of photographs and articles presented adults who were young and white, and lived with parents or spouses. The technological work they did also reflected these demographics, with mentions of single-family houses, cars, and a variety of consumer gadgets at the ready. The format of these community magazines also echoed the mass media of their time, with reports on home renovation and consumption delivered in the bright, optimistic tone of magazines such as Ladies' Home Journal or Popular Mechanics, with their respective gendered associations.

Emerging from the rigidly regulated world of postwar domestic life, these accounts present a view of technological work as both a triumph and a defense. On the one hand, the buoyant tone of many of the accounts related the joy of finding tools and arrangements that improved everyday routines. On the other, these writings depicted a population highly conscious of the stakes of rehabilitation. As disability historian Henri-Francois Stiker has observed, the modern concept of "rehabilitation" hewed to existing categories of respectability and acceptance. ${ }^{17}$ For each group considered viable for rehabilitation, there remained those considered incapable or unworthy of "return" to mainstream society. Adapting to the physical spaces and tools of white, middle-class life was crucial to maintaining status among the "acceptable." The enthusiasm of innovation and discovery in these narratives often shields an underlying fear about the possibilities of failure. 


\section{Technology from Hospital to Home}

For many people learning to live with new disabilities, the trials of finding useful and usable technologies began in the hospital. As patients moved from surgery or emergency medical care to rehabilitation, their doctors, insurance companies, and medical administrators exerted control over choices of medical equipment and physical treatment. Members of the medical establishment often ignored or dismissed patient input, assuming that whatever medical supply companies or research programs produced would be good enough. The difficulties encountered by people with disabilities in acquiring, fitting, and using assistive technologies introduced them to life on the margins of American culture. For many, experiences negotiating with and circumventing the medical equipment system instilled a sense that consumer products and technologies provided useful raw materials, not end products. Suitable, comfortable, and appealing tools for everyday life would require further intervention.

Rehabilitation treatment, whether in long-term residential facilities or outpatient clinics, involved a panoply of "adaptive" or "assistive" technologies. When acute cases of polio caused paralysis in the chest cavity, patients battled the peak of symptoms in an "iron lung" respirator, a full-body-sized tube with bellows-like air pressure mechanisms that forced the lungs to expand and contract. Rehabilitation doctors and therapists encouraged "weaning" from the iron lung, but many severely paralyzed patients continued to rely on the iron lung either full-time or for limited periods each day, particularly while sleeping. Respiratory polio came with a variety of other accoutrements, including "chest shell" respirators that were less powerful than the iron lung but wearable in a sitting position; rocking beds, which used a see-saw motion to force air in and out of the lungs through gravity; and standing beds, to which patients were strapped in order to come to a vertical position and stretch their legs. ${ }^{18}$ Patients with partial or even complete lower-body paralysis wore steel braces to support and straighten their legs and corsets to make their spines straight. ${ }^{19}$ The expense of this equipment was offset by support from charitable groups such as the NFIP, private insurance, or veterans' subsidies for many, but the tasks of selecting, fitting, and adapting these tools were battles of their own. ${ }^{20}$

The equipment that people with disabilities obtained through hospitals often fell short of ideal fit and function. Choices of equipment were limited: wheelchairs came in three sizes (adult, junior, and child, with the occasional addition of "adult narrow"), and braces in just small and large versions. ${ }^{21}$ Moreover, equipment was assigned based on a doctor's prescription, so the type of device might reflect an overly aggressive rehabilitation plan. Polio survivors remembered painful hours of trying to walk in steel braces and balancing precariously on crutches. ${ }^{22}$ Throughout the mid-twentieth century, doctors insisted that all but the most severely paralyzed patients should be able to walk, so long as they had, in the words of orthopedist Dr. Philip Lewin, "one good arm and an arm good enough to hold a crutch, [and] at least fair intelligence." ${ }^{23}$ Patients often dreaded fittings 
of whatever medical "appliances" they used, as well as follow-up appointments with doctors and therapists who might assign new, stringent exercise routines and brush aside complaints about discomfort. ${ }^{24}$ Mary Grimley Mason wrote in her memoir of polio that a tight new brace "felt as if a hundred little fingers were pinching me up and down my legs," and that the brace-maker adjusted it only reluctantly, mumbling that she "was probably just not used to them." 25

At a time when Americans had access to an ever-widening array of consumer goods in hardware, grocery, and department stores, the market for medical equipment remained firmly separate from mainstream consumer culture. Though the number of Americans who used assistive technologies was significant—one survey conducted in the late 1950s counted just under a million Americans who used wheelchairs, arm or leg braces, or artificial $\operatorname{limbs}^{26}$ — manufacturers made few direct appeals to users, opting instead to target marketing to medical providers and hospitals. ${ }^{27}$ Medical professionals and equipment suppliers asserted that patients needed their help and guidance. Mid-century practitioners would likely agree with the doctors, prosthetists and orthotists interviewed for a survey in 1976: they all agreed that "consumers [should] avoid the risks of shopping on their own in all instances." 28

Even when patients did order their own equipment, they encountered an industry not organized to serve the individual buyer. Many wheelchair companies produced a variety of metal goods, of which hospital supplies were just one category: for example, the Colson Corporation, one of the largest wheelchair makers of the mid-century, manufactured carts and casters, and, as an offshoot, wheelchairs. Their catalogs devoted dozens of pages of wheels and carts before one or two with wheelchairs. Descriptions were brief, with listings simply declaring "sturdy construction" or touting easily replaceable, smooth-running "ball-bearing wheels." ${ }^{29}$ The images in Colson's catalog showed wheelchairs in hospital settings, not in homes or in public. In these trade materials, wheelchair companies affirmed the message that these were products for medical, not consumer use, and that people who used wheelchairs did not fit easily into home or public environments.

In addition to prescribing assistive equipment to help patients "overcome" disability, rehabilitation specialists acknowledged the difficulty many people with disabilities would still have operating everyday products and navigating standard environments. At the New York Institute for Physical Medicine and Rehabilitation, leading rehabilitation expert Dr. Howard Rusk included a "SelfHelp Aids" workshop where staff showed patients simple tools for daily activities. For example, eating utensils could be altered with metal loops or foam padding, or razors and combs given extended handles for easier manipulation. ${ }^{30} \mathrm{Few}$ of these devices were manufactured products, but instead were devised over the years by staff and patients themselves. Rusk and his New York Institute colleague Edward Lowman wrote in articles and books of the lack of mass-market products for everyday lives of people with disabilities. They suggested, however, that many solutions could be found among the "gadgets" of mid-century 
consumer culture. "The 'gadget era' has particular implications for the person with a physical limitation," they wrote in a 1952 volume entitled Living with a Disability, urging readers to look beyond medical supplies. They encouraged patients to "try the hardware, department, and other stores, or seek help from your classified telephone directory for further assistance on what's available or new," and noted that the do-it-yourself magazine Popular Mechanics was "full of useful suggestions." "31

"Self-Help Aids" of the postwar era are artifacts of Rusk's and other rehabilitation specialists' assumptions and expectations about disability. Disability historians have traced the many ways in which cultural values influence medical prescriptions. For example, the ever-present goal of "walking again" was a relatively new development in the mid-twentieth century. In earlier periods, when one's gait was socially paramount, this goal was not a primary interest since walking imperfectly was seen as worse than not walking at all. ${ }^{32}$ The "independence" that doctors and therapists, and even patients, envisioned for life outside the hospital entailed adjusting oneself - "helping" oneself - to fit into a society with virtually no accommodations for disability ${ }^{33}$ Traces of the "Self-Help" approach to rehabilitation remained as people with disabilities and their families sought to address the realities of life in the houses, on the streets, and among the products of 1950s and 1960s America. The so-called "gadget era" did present many potentially useful objects for people with disabilities, though few of these were manufactured with that intention. As chronicled in the Toomey J Gazette and Paraplegia News, people with disabilities made creative use of available products and materials to improve their own comfort and pursue their own interests. As they renovated and rearranged their houses, selected useful products from the mainstream marketplace, and altered others to make them useful, people with disabilities found ways to use technology to their own advantage. In doing so, they asserted their own presence in a world that largely ignored them.

\section{Constructing a Life at Home}

In his memoir of polio, Charles Mee remembered stumbling home the night the virus set in. Out on a high school double date at a friend's house, the ache in his belly and weakness in his legs became too much to ignore. Mee described making his way home on rubbery legs, a trek of "maybe fifteen blocks... these were small-town suburban blocks, brick and wood frame houses from the twenties and thirties mostly, some new ranch houses with big lawns both front and back; I knew just which back yards I could cut through." ${ }^{34}$ This was the neighborhood he would leave that night to go to the hospital, and the same one to which he would return after treatment for acute polio and rehabilitation for paralysis in his legs. The particular setting of Mee's upbringing was common to many polio patients. The disease disproportionately affected white, Western and Northern communities of the United States, areas in which rigorous use of modern sanitation reduced the chances that children would develop immuni- 
ties through exposure in infancy, and where geographic mobility increased the spread of the virus. ${ }^{35}$ People of all regional and class backgrounds who became disabled in the postwar decades returned from hospital care to a world that was not built for them. ${ }^{36}$ Details in architecture and landscape they may never have noticed before - the slope of a driveway, the height of a countertop, a tricky doorknob - now had new significance.

The worlds that polio survivors described in the Toomey J Gazette would have been familiar to Mee. Many of the magazine's correspondents depicted lives in single-family houses in the suburbs or small towns, surrounded by consumer technologies and accompanied by a nuclear family. The work they described, too, echoed familiar activities of middle-class, mid-century domestic life. Whether sewing their own slipcovers and curtains, installing cabinets in their kitchens, or soldering and welding in their garages, middle-class homeowners performed a variety of creative and skilled work to maintain and improve their homes, furnishings, and automobiles. ${ }^{37}$ Do-it-yourself activities allowed men and women of the 1950s and 1960s to express individual taste and style in the mass-produced consumer culture of postwar America. ${ }^{38}$ Despite a shared sense of excitement over clever and useful adaptations, these projects carried high stakes for people with disabilities. Eating, dressing, bathing, and getting around the house provided a sense of personal independence, particularly for those who, like Ida Brinkman and her fellow "respos," required family or attendant help in many basic activities. If suburbanites who built additions to their subdivision houses and accessorized their cars did so to distinguish themselves as tasteful or creative, people with disabilities did the same work to fit in, to prove their worthiness of inclusion in a society where many considered the severely disabled to be incapable or unworthy of rehabilitation.

For households with a physically disabled family member, the house itself often presented a technical challenge. Small, single-family houses were common in many American communities, from urban neighborhoods built in the 1920s and 1930s for a new industrial working class to the rapidly expanding suburban "Levittowns" constructed in the post-World War II years. ${ }^{39}$ The efficient, modestly scaled Levittown Cape Cod houses that were first built in 1947 on Long Island included doorways 28 to 29 inches across and hallways not much wider. ${ }^{40}$ Standard-sized wheelchairs, which typically measured 25 to 29 inches in width, not to mention iron lungs and rocking beds, fit awkwardly into these spaces. ${ }^{41}$

Contributors to the Toomey J Gazette wrote of small and large home renovations to accommodate wheelchairs and other equipment. One "Brainstorms" column included the suggestion of cutting a hidden swinging door into the existing wall adjacent to a doorway, providing space to move equipment when needed [Figure 3]. ${ }^{42}$ With the hidden door "papered to match," the house's décor could remain complete even with the new presence of unwieldy equipment. Other suggestions hinted at the same problem. Readers wrote in with descriptions of improvised "wheelchair narrowers," contraptions that consisted of wire hangers or a belt looped around the handles to draw a chair inward by an inch or two 


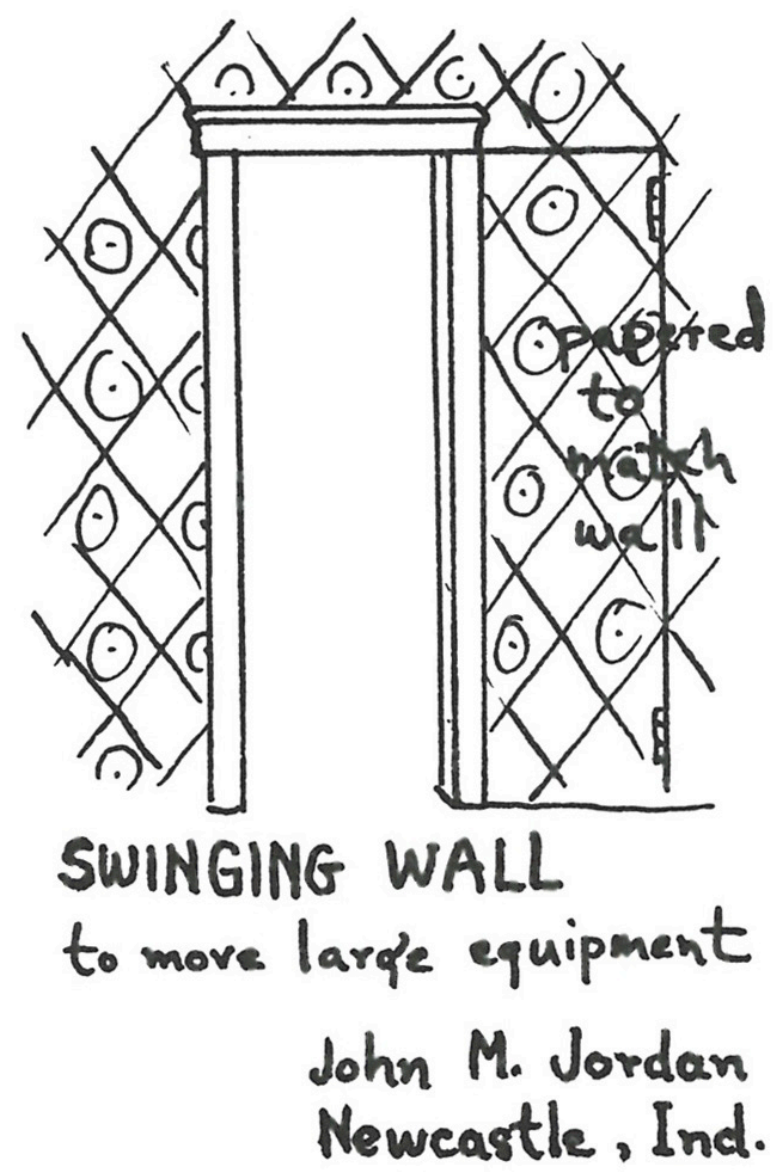

Figure 3: Swinging Wall, in "Brainstorms," Toomey J Gazette, Fall-Winter 1959, 16. Courtesy of Post-Polio Health International.

to fit through these passageways. ${ }^{43}$ Commercial versions were also available, promising to squeeze a wheelchair in by as much as four inches using a hand crank mechanism [Figure 4]. ${ }^{44}$

As they conducted patchwork renovations on their houses, families sought to balance practical concerns of disabled and non-disabled inhabitants. One couple sent the Toomey J Gazette photographs of the clever ramp built by the husband for his wife [Figure 5]. ${ }^{45}$ The long ramp, calibrated to keep a gentle slope, hugged the side of the house, leading to a side door. Since this addition blocked the front stoop, the man added a trap door for the ramp that could be raised off of the stoop to give access to the steps below. Inside houses, barriers 


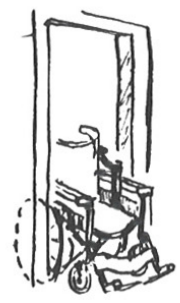

- Wheelchair narrower - Narrows 4". Fits all chairs. Operated by cranking handle attached to either right or left side of wheelchair. \$39.50. Kendell Enterprises, 2714 Holly Avenue, Arcadia, California

Figure 4: Wheelchair Narrower, in "Equipment," Toomey J Gazette, SpringSummer 1962, 42. Courtesy of Post-Polio Health International.

built into the layout were even more difficult to remedy. In some cases, families had to move or conduct extensive renovations to accommodate a disabled relative. Ed Roberts, a prominent participant in the Disability Rights Movement, was almost completely paralyzed from the neck down after his teenage case of polio. His family moved to a new house after he returned from the hospital so his hospital-style bed could fit in the dining room. ${ }^{46}$ The family organized activities together around Ed's bed rather than transfer him to a wheelchair and strap him into a corset for everyday activities. His wheelchair was of limited use beyond the threshold of the house, given poor street-level accessibility during his adolescence in the late $1950 \mathrm{~s} .{ }^{47}$

Over the weeks and years following rehabilitation, families continued making adjustments to their everyday environments. Women who took on homemaking roles after polio or other paralyzing conditions became consumer product testers, vetting new gadgets and materials from the standpoint of their own physical needs. The 1968 issue of the Gazette featured an eleven-page section on "Homemaking" with forty readers' suggestions on arranging kitchens, doing laundry and cleaning, and cooking from wheelchairs or with limited manual strength or dexterity. ${ }^{48}$ Their notes describe everyday life within households where floor plans, furniture and appliances posed obstacles. Readers wrote of such practices as filling a pot on a stove one cup at a time, as the height of the standard stove made it awkward for a wheelchair user to lift a full pot from sink to stovetop. To use outlets at the back of countertops - hard to reach from a wheelchair or with limited mobility - they connected extension cords, while mirrors hung over stoves to provide a view over back burners. Some contributors described the challenge of using small drawer handles and stiff faucet heads with shaky or paralyzed hands. "I 


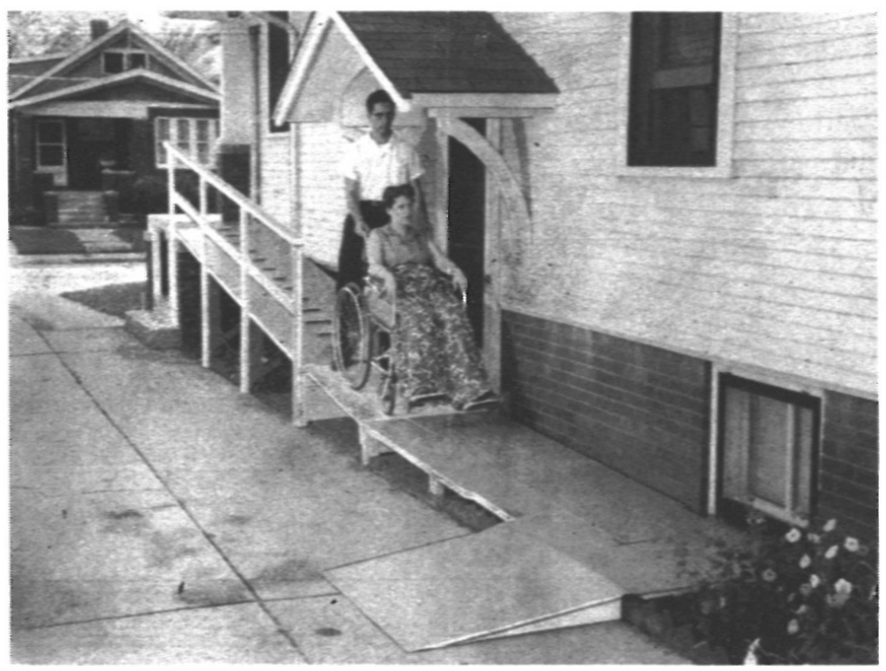

PLYWOOD PLATFORM IS LOWERED into position by rope to connect head of ramp with porch floor. Platform is stored on porch when ramp is not being used

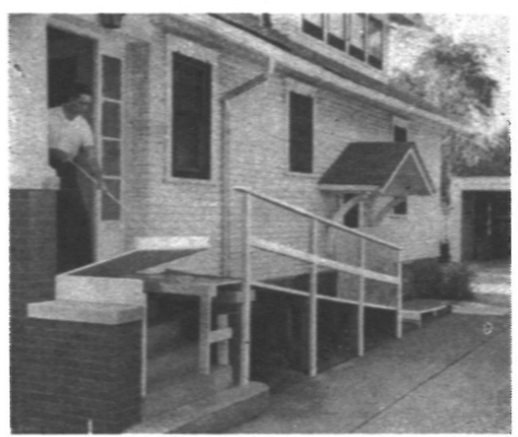

HINGED "DRAWBRIDGE" across side entrance is swung back onto ramp when latter is not being used so that door can be opened without interference

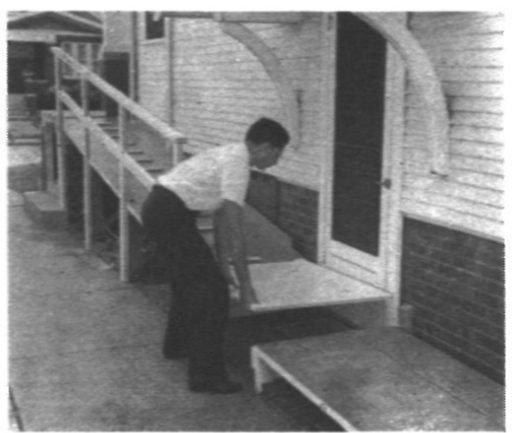

Figure 5: Home wheelchair ramp, in "Equipment," Toomey J Gazette, Spring 1961, 11. Courtesy of Post-Polio Health International.

walk my fingers around the sink to the water faucet," wrote one; another used "a long wooden spoon with four nails in the bowl section" to twist the small handles [Figure 6]..$^{49}$ Some wrapped rubber bands around "small slick knobs," while one contributor, perhaps frustrated with various experiments, suggested that "if you are unable to use the hardware on drawers and cabinets, just skip it and fasten on inexpensive towel racks for easy pulling." ${ }^{50}$

People with disabilities balanced the frustration of contending with the design of mass-market products and furnishings with pride and delight in finding the right tools for a given job. Contributors advised careful selection, suggesting that 
- "I use a long wooden spoon (A) with four nails in the bowl section. Wrap nails with electrician's friction tape." - English booklets list both homemade and commercial models of tap turners:

(B) For a single bar tap, a groove whittled out of a cylindrical piece of wood.

(C) A tap turner made of a length of wood, a drilled hole, and two cup hooks.
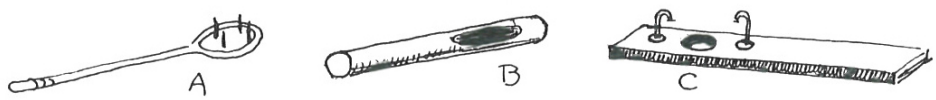

Figure 6: Faucet turners, in "Homemaking," Toomey J Gazette, 1968, 18.

fellow readers " $[\mathrm{t}]$ hink about weight as opposed to ease of handling... Handles are quite different on knives. Very individual decision is needed here." 51 This kind of individual decision-making, based on one's relative strength and coordination, as well as personal taste, engaged people with disabilities in an intensive form of shopping. The women homemakers - as well as some bachelors and husbands - who wrote to the Gazette took careful note of brand names, noting specific models of automatic can openers, electric knives, and mixers they found most promising for persons with limited hand strength. For those who fumbled with glass and ceramic dishware, new plastics offered more than just colorful or airtight storage: "Bless Tupper Ware [sic]" wrote one contributor, "you can drop it and it doesn't fly open and spill contents." 52

The Gazette's special "Homemaking" section echoed the tone and look of mainstream domestic literature. The section featured a two-page drawing of ways to arrange kitchen equipment, with crisp outlines of pegboard storage, lazy Susans, and pull-out shelves to hold efficient, organized rows of pots and pans, dishes, jars, and bottles [Figure 7]. The outlines of dishware and familiar appliances recall the geometry of mid-century consumer magazine layouts, which showed products floating in space or tidily arranged in ideal kitchens. ${ }^{53}$ The "Homemaking" tips, as well as other reader-contributed household tips, were particularly reminiscent of the format of "Hints from Heloise," the domestic advice column that was nationally syndicated after $1961 .{ }^{54}$ In her column, Heloise Cruse published submissions by readers, who shared tips and shortcuts for using everyday items, such as looping a soda-can tab over a hanger to store a belt with its matching outfit; keeping out-of-season clothes in empty suitcases to maximize storage space; and setting plywood atop rubber bands to provide a "rolling platform" for a stand mixer and eliminate "lifting or tugging." ${ }^{55}$ Heloise rewarded her readers with occasional comments like "what a smart cooky [sic] you are!" and "that's a really sneaky one. And it works like a charm." Heloise even included a few hints from women with disabilities, such as an 88-year-old reader whose daughter altered a hanging shoe bag to make pockets for her walker, 

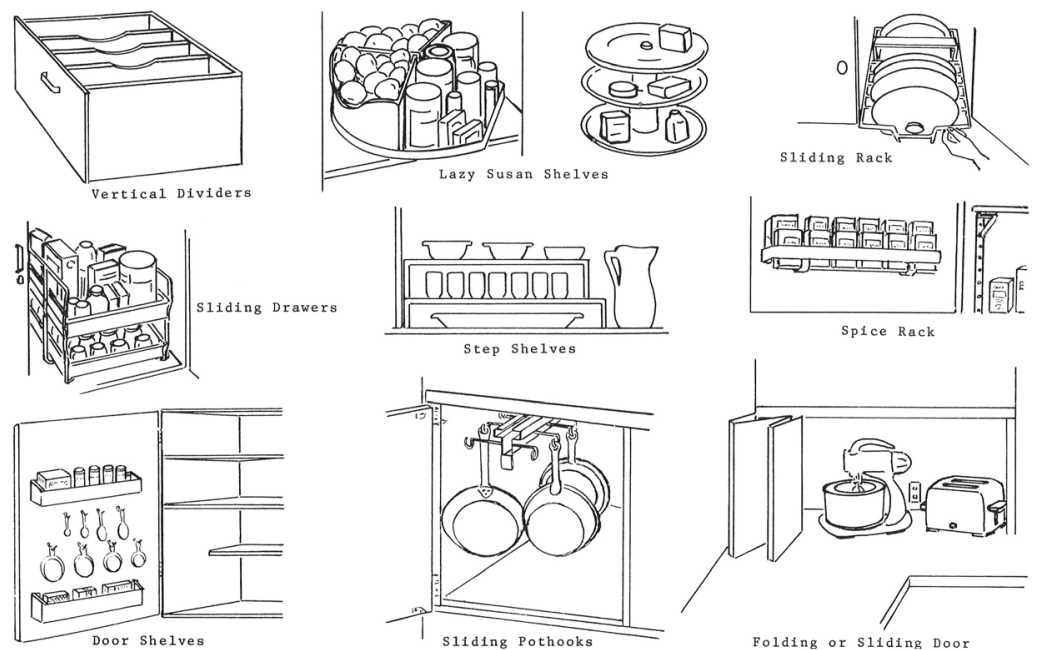

Figure 7: Storage, in "Homemaking," Toomey J Gazette, 1960, 24-25. Courtesy of Post-Polio Health International.

and a woman amputee who shared a "hint" for attaching a cleaning brush to a cutting board for one-handed vegetable scrubbing. ${ }^{56}$

Although their needs were more specific than those of homemakers concerned about storage space or matching belts, contributors to the Toomey $J \mathrm{Ga}$ zette showed some of the same creative excitement over the world of consumer products conveyed by Heloise's columns. A page from a Spring 1960 Toomey $J$ Gazette featured sixteen different designs for homemade "mouthsticks"- tools used in writing, typing, and other actions in replacement of hand movement-in a cheery, sunburst layout [Figure 8]. ${ }^{57}$ People with limited use of their arms and hands used these sticks, assembled from various available materials, to type, write, dial the telephone, and do other small tasks using their mouths for leverage. In the mouthsticks illustration, the simple implements radiated out from a sweetly outlined mouth. One stick with a paintbrush attachment pointed inward, completing the illustration and suggesting the action of "mouthstick" painting, a common hobby taught in rehabilitation centers and often celebrated in the Gazette. ${ }^{58}$ The materials used in the "mouthsticks" were of the moment, incorporating the novelties and synthetics that were newly available for affordable consumption in postwar America. ${ }^{59}$ Most were made of simple dowels or pens, with rubber erasers or eye-dropper tips to provide a soft surface to be gripped between the teeth. Some incorporated more novel materials, such as the rubber heel of a doll's shoe, a cigarette holder, and a spring-loaded clamp that could be operated with the tongue. The illustration of these different options and the cheery mouth at the center takes a cue from the visual culture of the 1950s: we can almost imagine a similar layout in an advertisement or magazine editorial 


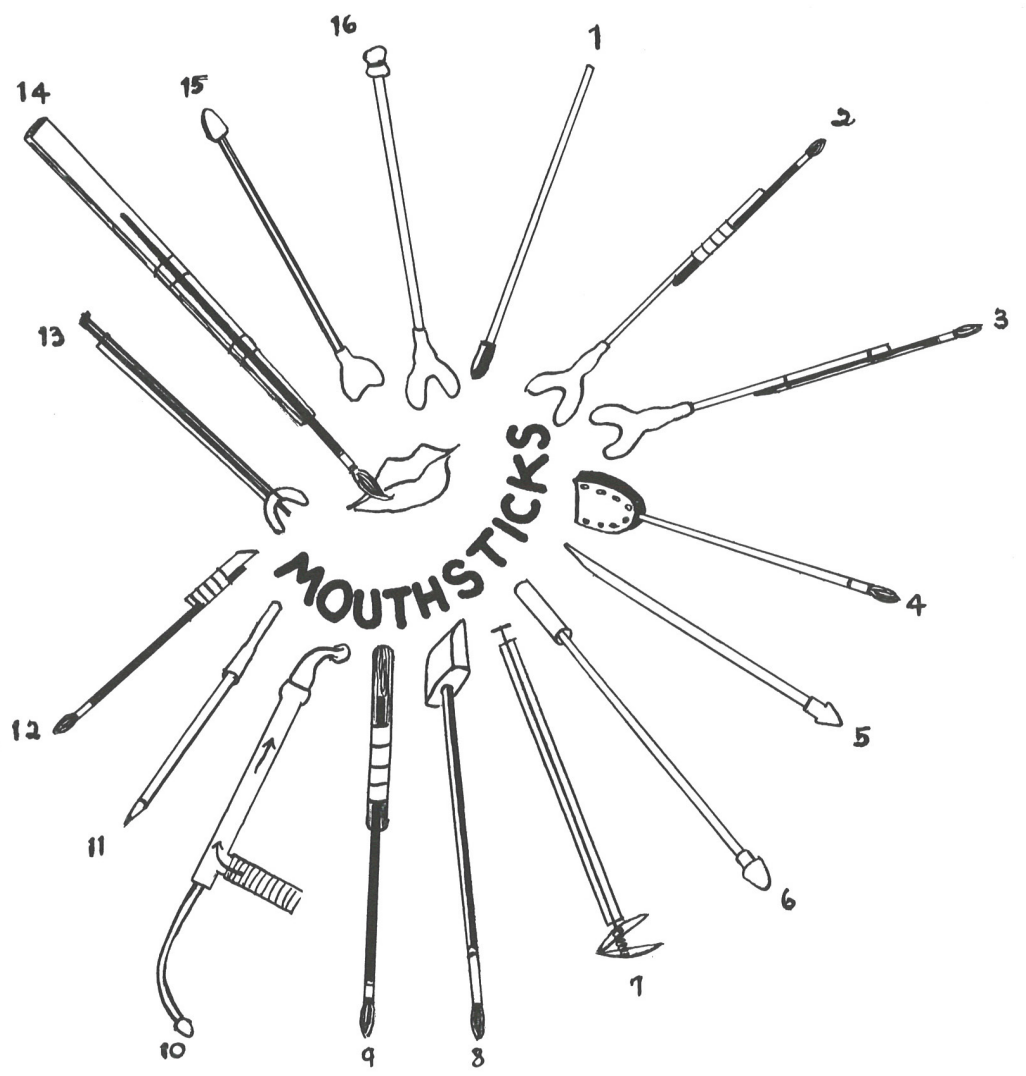

Figure 8: "Mouthsticks," Toomey J. Gazette, Spring 1960, 8. Courtesy of PostPolio Health International.

showing kitchen utensils or lipsticks. In these collections of readers' inventions, the Gazette translated some of the light, joyous appeal of mid-century consumer culture into the world of highly specific and personal assistive equipment.

The upbeat, optimistic tone in which Toomey J Gazette contributors described finding the right drawer-pull or the best page-turner suggests a distinctive role for consumption in the lives of people with disabilities living at home in this era. Interactions of people with disabilities with the world of products and spaces reinforced their difference from the mainstream. In these intra-community documents, however, they presented technical adaptation as part of familiar, expected activities of household life, akin to the housework or home decoration discussed in women's home magazines of the time. Layouts such as the "Homemaking" article depicted the tasks of finding and customizing consumer goods as com- 
ponents of class- and gender-specific roles of the postwar household. In a final category of adaptation - the use of automobiles - people with disabilities took a creative approach to technology to take part in public life as well.

\section{Access on the Road}

Although people with disabilities could create a modicum of access within their own houses, they could do little to change the abundance of street-level barriers in American cities and towns. Accessible architectural features in public buildings such as curb cuts, widened doorways, and public toilets with spaces for wheelchairs were virtually unknown until the 1960s, when the American National Standards Institute first provided a guide to these measures. Even as local and state governments adopted this standard, compliance was uneven. ${ }^{60}$ As one polio survivor described his life after returning from rehabilitation in the 1950s, his family's alterations to their house to facilitate wheelchair use were "enough to help, but not enough to get me accustomed to living in any sort of specially constructed world" given pervasive barriers beyond the household. ${ }^{61}$

In this era before ramps and curb cuts, people with disabilities found ways to move about in their communities, albeit with great difficulty and unpredictability. Some wheelchair users told of riding in the street to avoid curbs, entering traffic until they found driveways or other breaks in the sidewalk. ${ }^{62}$ They relied on friends, family, or passing strangers to help them get over curbs and up front steps, an uncomfortable and often frightening experience. ${ }^{63}$ Portable ramps - both commercially manufactured and homemade - could be used to traverse a small number of steps, but often required the help of a companion to set up and take down these cumbersome devices. ${ }^{64}$ Some industrious inventors devised more complicated devices, such as the "outdoor elevator" described by Vince La Michle in a 1958 article in the Toomey J Gazette. Powered by a 1/6 horsepower motor, the elevator raised or lowered at one inch per second and was, according to La Michle, "certainly easier than a ramp. ${ }^{965}$ Whether rudimentary or complex, these devices were attempts to bridge the gap between desires to enter the public world and physical barriers in the American landscape.

One of the most-discussed tools in the Toomey J Gazette and the Paraplegia News was not a piece of "assistive" equipment, but an iconic technology of the twentieth century: the automobile. Historians of American car culture have used the term "automobility" to describe the way in which the personally driven motor vehicle became linked with a sense of freedom and independence. ${ }^{66}$ For drivers and passengers with disabilities, automobility had an extra layer of meaning, as it offered a chance to move freely past street-level barriers such as steps and curbs. In pursuit of what the Toomey J Gazette called "quad driving," people with disabilities became auto enthusiasts of a very distinctive kind. ${ }^{67}$ They took advantage of new technological devices in the mainstream automobile market, including the automatic transmission and various add-on accessories. Others enlisted the help of family members and independent mechanics to assemble 
and accessorize cars that could be driven by hand or with one leg. "Quad drivers" operated on the fringes of an existing technological culture, deploying car technologies to achieve their own form of automobility.

The first devices that allowed people to drive with limited or no use of their legs targeted an elite audience. De Soto developed a custom hand-operated model for President Franklin Delano Roosevelt in 1933, which he test-drove at Warm Springs, the polio rehabilitation center in Georgia that he founded and visited throughout his presidency. ${ }^{68}$ In the following year, Warm Springs' in-house magazine, the Polio Chronicle, extolled the promise of several new, patented hand controls to let "the President and other polios become their own chauffeurs. ${ }^{"}{ }^{99}$ Self-driving was not a necessity for many Warm Springs patients, since they came from social circles where employing drivers was the norm, yet hands-on experience had its own appeal. Despite Roosevelt's enthusiasm, the hand controls of the 1930s and 40s were difficult and dangerous to operate. Driving a manual-transmission car entirely by hand meant juggling levers for brake, clutch and accelerator pedals, all the while operating the steering wheel. Inventors tried several approaches to dual clutch-brake hand control, including buttons and switches allowing the driver to use the same handle to depress the clutch alone, or the clutch and brake pedal at the same time. Still, these left the driver with no option for using the clutch and brake pedals independently: for example, to ease the brakes off slowly when starting on a hill.

The greatest technological improvement for drivers with disabilities was not a new hand control, but the automatic transmission. Automakers introduced a few models with automatic transmissions in the early 1930s; they became widely available in the $1940 \mathrm{~s} .{ }^{70}$ This new technology coincided with a new demand for cars for people with disabilities, particularly disabled veterans, who could receive a government benefit of up to $\$ 1,600$ towards the cost of a handcontrolled or otherwise adapted vehicle. ${ }^{71}$ This subsidy made cars and driving a distinct component of veterans' culture, with models and accessories discussed in a special "Hand Controlled" column in the Paraplegia News. The column's author, Joe Jordan, wrote of the special connection veterans had to cars, noting that "there is very little controversy and possibly near unanimous agreement that 'mobility,' our effort to get around once again, rates a high and very special place among [veterans'] problems." ${ }^{\prime 2}$ As Jordan noted, however, not all available vehicles worked well for the needs of disabled drivers. Even with an automatic transmission, drivers had to vet the specific configurations available, since many name-brand "drives" still required some clutch-shifting by foot. ${ }^{73}$ The Oldsmobile Hydramatic, for example, which had a clutchless shift mounted on the steering column, was "widely used" among veterans, according to Jordan.

In the pages of the Toomey J Gazette, people with disabilities and their families showed off a broad variety of customized cars that went far beyond commercially available models with hand controls and automatic transmissions. Fred Taberlet's "Para-car," described in a 1968 Gazette article, was a Citroen 2 with the top and back completely cut off to make room for an elevating floor. 
Accompanying photos featured Taberlet lifting himself, wheelchair and all, into the driver's position, eliminating the need for help in climbing into the driver's seat or stowing a wheelchair [Figure 9]. ${ }^{74}$ The customized vehicle had not one, but two sets of hand controls, so that Fred could rotate himself completely and drive the car forward or backwards, keeping him from having to crane his neck to see while driving in reverse. Fellow Gazette contributors showed off other creative approaches to driving. One British reader displayed a pair of leather "mitts" that helped him grip his hand controls. For those with more coordination in their legs and feet than upper extremities, an American entrepreneur developed "a kind of ski boot attachment" that could be used to operate the steering wheel by foot. ${ }^{75}$

"Quad driving" was for passengers as well. For people whose impairments meant that they would never drive themselves, riding in a car was a way to participate in public without being strapped into a wheelchair, let alone contending with steps, curbs, and the stares of other people. Ida Brinkman named drive-in movies as a favorite activity of her family and showed off a special head rest she used in the family car. ${ }^{76}$ Other families went to dramatic lengths to include their disabled relatives in car travel. More modest than Fred Taberlet's Citroen convertible, but no less inventive, were the alterations the Ray family made to their family car so they could travel with their daughter Susan and her reclining wheelchair and respirator [Figure 10]. Susan's father Cecil, a Baptist minister (and "mechanical whiz," according to his wife), removed both front and back seats on the passenger side of their 1955 Ford station wagon and installed a smooth platform for her recliner. He moved the post between doors and re-hinged the rear door, making a double-wide entrance for Susan in her chair. The Rays traveled with a small homemade trailer with compartments for extra respiratory equipment and doors on both sides for easy access. The family reported traveling in this car from their home in San Antonio, Texas, to the Southern Baptist Convention in Miami, Florida, and national parks in the Smoky Mountains, Yellowstone, Mesa Verde, Arches National Monument, and the Grand Tetons. ${ }^{77}$

The customized cars driven by people with disabilities and their families likely turned heads in town, but they were not alone on the road. Local mechan-
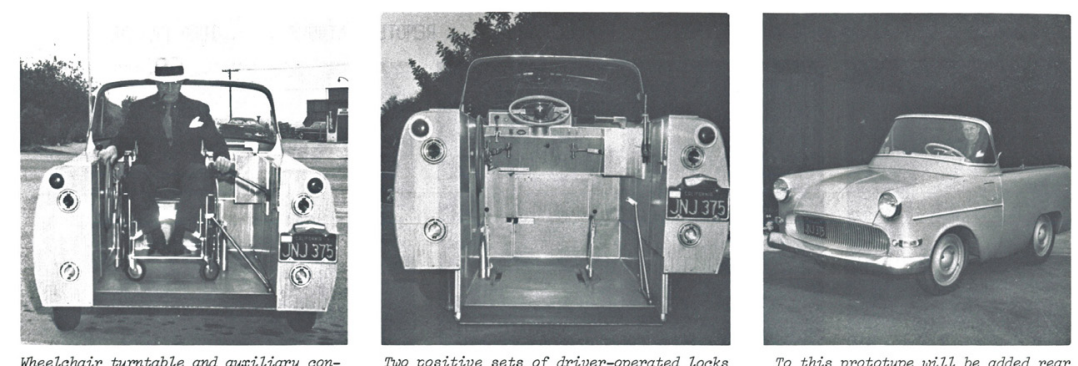

Figure 9: Para-Car, in “Equipment," Toomey J Gazette, 1968, 54. Courtesy of Post-Polio Health International. 


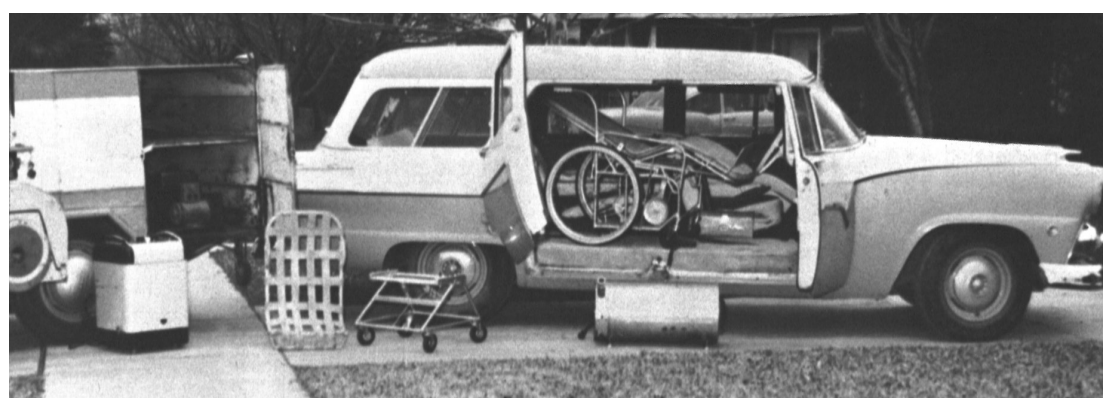

Figure 10: The Ray family wagon, "Travel by Respos," Toomey J Gazette, Spring 1961, 18-19. Courtesy of Post-Polio Health International.

ics who installed specialty equipment had experience customizing cars for other uses, such as hot-rodding or camping. They might even come across familiar equipment. For example, many catalogs and articles on adapting cars for use by people with disabilities suggested installing a knob for the steering wheel to aid driving with a prosthetic or a single hand. ${ }^{78}$ These knobs were not exclusive to the community of disabled drivers, but were available as options from major car manufacturers throughout the 1940s and 1950s. Though they ostensibly offered a more secure grip for any driver, they were known colloquially as "necker's knobs" for one-handed drivers who kept one arm around their dates. ${ }^{79}$ Disabled drivers had most in common with fellow tinkerers who altered sedans, station wagons, and buses for long travel. As the auto historian Roger White has explored, in the days before the commercial introduction of "Recreational Vehicles," car owners made motor homes by removing back seats to make room for beds, hanging curtains for privacy, and installing shelves to hold amenities like camp stoves and washtubs. One driver described the joy of a "carefree Gypsy life" to be found in extended trips in his custom motor home. ${ }^{80}$

People who altered familiar technologies to work for their own disabled bodies shared much with their nondisabled counterparts. As with household technologies, these tools took on different meaning for a population for whom everyday mobility could be difficult or impossible. "Quad driving" provided a version of access that people with disabilities could not experience on the sidewalks of their hometowns, but it also allowed disabled drivers to participate in the American hobbies of picking out, tinkering with, and finding adventure in automobiles.

\section{Technology and Rights in the Twentieth Century}

These disabled tinkerers and inventors join a long history of consumers who reconfigured products of the mass consumer culture for their own needs. Historians have traced examples of consumers who altered mass-market technologies for their own distinctive uses, from rural farmers who used early automobile mo- 
tors to power appliances in their houses, to indigenous groups who appropriated tourists' video cameras to tell their own stories of cultural endangerment. ${ }^{81}$ For those on the fringes of society, appropriation can be the only means of finding tools to operate for one's own needs - be they mechanical, personal, or cultural - when manufacturers and advertisers target other populations. In claiming consumer citizenship in these ways, people with disabilities acted from a position of marginality, but did not seek to resist or subvert mainstream culture. Their technological efforts were acts of integration, not resistance, into the normative roles for men and women of their class and race.

These technological efforts to "fit in" to the spaces of postwar life were a form of self-preservation in a society that presented few options for people with disabilities to live independently. When "Electric Mom" Ida Brinkman confessed to Toomey J Gazette readers that she had been "secretly frightened" about her return home, she voiced a feeling many readers and writers of the Gazette surely felt. The insecurity with which people with disabilities lived during this time should not be underestimated, particularly for those whose injuries or impairments necessitated daily assistance. The specter of being locked away in an institution hovered over many, especially those who were poor or whose disabilities resulted from injuries or diseases not supported by the March of Dimes or other charities. Those who returned home from rehabilitation were hardly exempt from these worries. In less optimistic narratives than those of the Toomey $J$ Gazette, some polio memoirists reported isolation and mistreatment in their home lives, with their parents or spouses who left them in bed for days, withheld help in bathing or eating, or, worse, took out their frustrations in emotional and physical abuse. Even people with severe disabilities who, like Brinkman, had families willing and able to support them had to wonder what would happen if family members died or could no longer assist them. Starting with the "daily life" training they received in hospitals, people with disabilities got a strong message that they needed to show continual progress and a good attitude, lest they be labeled "bitter" or "uncooperative." $\$ 2$ While they experienced some excitement from creative work on their kitchens, cars, and houses, these technical tasks were also a constant reminder that the burden was on them to adapt, not on the society at large to provide accommodations. Whether they performed this technological work themselves, or with the help of handy family members, adapting to the inaccessible built environment remained a private affair.

In the eleven-year run of the Toomey J Gazette, there were only small hints at a sense of political identity emerging from this community network. In a 1959 editorial, Sue Williams, who took on a primary editorial role alongside "vertical" editor Gini Laurie, warned readers of the Gazette of the need to turn the attention directed towards polio cases into long-term, sustained support. "The "iron lung story' that has been told about each of us was a heart-wringer and a purse-opener," she wrote, referring to the pitying gaze of the mainstream media. ${ }^{83}$ "Now that we cease to be a sensation in this way, there is quiet un-newsworthy work for us to do," she continued, including insisting on long-term home care funds to alleviate 
readers' dependence on their families for care. Four years after the discovery of the Salk vaccine, these "polios" were aware that their time in the spotlight was coming to an end. Others who lived during this period later reflected on their experiences of pressure and condescension. Mary Lou Breslin, who grew up with a polio-related disability in the 1950s and 1960s and later became active in the Disability Rights Movement, remembered feeling pressured to present an image of flexibility and positivity, despite the everyday strains of operating as a wheelchair user in public. She described this false front of confidence and ease as "shucking and jiving," drawing a parallel between this behavior and African American minstrelsy. ${ }^{84}$

The comparison Mary Lou Breslin made between herself as a successful rehabilitant in postwar America and African Americans who performed to white expectations reflects the perspective of one looking back, after an awakening to disability rights, at the "bad old days" of the 1950s. Like many who participated in social movements of the later twentieth century, Breslin saw the optimism and homogeneity of postwar culture as a false veneer hiding tensions that would later become apparent in the upheavals of the late 1960s and 1970s. The Toomey $J$ Gazette and other disability-community periodicals conveyed a more positive tone as individuals shared their stories of returning to family and home. Searching for accessible tools in the "gadget era" - as Howard Rusk and Edward Lowman dubbed it — was a practical approach to the problem of outsider status in postwar society. In an era before civil rights laws required some measure of physical access in the built environment, people with disabilities used and adapted technologies of everyday life to close the gap between the promise of inclusion and the reality of the world in which they lived.

\section{Notes}

Bess Williamson would like to thank the Mid-America American Studies Association and the editors of American Studies for their guidance and encouragement. This article began as a graduate conference paper, and gained significantly from the thoughtful and often quite detailed suggestions of several anonymous reviewers. It also benefitted from readings in the Chemical Heritage Foundation's CALCIUM workshop series, and from Drs. Arwen Mohen and Susie Strasser's dissertation group at the University of Delaware. Finally, thanks go to Post-Polio Health International, who have scanned the entire archive of the Toomey J Gazette and generously provided image permissions for the illustrations in this article.

1. Ida Brinkman, "The Home and I," Toomeyville Jr Gazette, Winter 1958, 13.

2. Ibid., 13-14. Throughout this article, I use the term "people with disabilities" to describe people with physical impairments - people variously called, in their time, "handicapped," "crippled," "disabled," "totally disabled," and by shorthand noun versions of medical conditions, e.g. "polios," "respos," "quads," "paras," or "parals." Scholars in Disability Studies vary in their chosen terminology. Here I employ "people-first" language, which I see as the most neutral of description. Some scholars prefer the adjectival description "disabled people," a term more strongly associated with the politics of disability rights and the idea that people are "disabled" by various forces, including the categories of culture, the state, and medicine. Further, some have pointed out the problems of "people with disabilities," in that it implies a separation of "personhood" and disability, and potentially reifies pejorative characterizations of disability. I chose the more neutral form - acknowledging its limitations - given that the people I discuss in this article rarely claimed an explicit political position as "disabled" (as I address in the final pages of the article). For further discussion, see Jacqueline Vaughn Switzer and Jacqueline Vaughn, Disabled Rights: American Disability Policy and the Fight 
for Equality (Washington, D.C.: Georgetown University Press, 2003), 10-11; and Paul K. Longmore and David Goldberger, "The League of the Physically Handicapped and the Great Depression: A Case Study in the New Disability History," The Journal of American History 87, no. 3 (December 2000), n. 2, 889.

3. Ibid., 15.

4. "Happy Birthday," Toomey J Gazette, Fall-Winter 1959, 9.

5. David A. Gerber, "Disabled Veterans, the State, and the Experience of Disability in Western Societies, 1914-1950," Journal of Social History 36, no. 4 (Summer 2003): 904; Edward D. Berkowitz, "The Federal Government and the Emergence of Rehabilitation Medicine," The Historian 43, no. 4 (Winter 1981): 530-531; S. Harry Berns et al., Spinal Cord Injury: Rehabilitation Costs and Results in 31 Successive Cases Including a Follow-up Study, Rehabilitation Monograph XIII (New York: The Institute of Physical Medicine and Rehabilitation, New York University-Bellevue Medical Center, 1957).

6. Stephen L. Percy, Disability, Civil Rights, and Public Policy: The Politics of Implementation (Tuscaloosa: University of Alabama Press, 1989), 110.

7. This "gap" could also refer to "the gap between representation and reality," the metaphor Rosemarie Garland Thomson uses to describe the divide between disabled persons' own sense of self and limited cultural perceptions of disability. Rosemarie Garland Thomson, Extraordinary Bodies: Figuring Physical Disability in American Culture and Literature (New York: Columbia University Press, 1997), 12.

8. Dr. Howard Rusk became one of the leading voices for a rehabilitation practice that would prepare the disabled for "independent" lives. See Howard A. Rusk, "Rehabilitation: The Third Phase of Medicine," Canadian Medical Association Journal 61 (December 1949): 603-607; Howard A. Rusk, New Hope for the Handicapped: The Rehabilitation of the Disabled from Bed to Job (New York: Harper, 1949). For more on Rusk and postwar rehabilitation, see Edward Berkowitz, "The Federal Government and the Emergence of Rehabilitation Medicine," The Historian 43, no. 4 (Winter 1981): 530-545.

9. "Masthead," Toomey J Gazette, 1967. The Toomeyville Junior Gazette, or Toomey J Gazette, ran from 1958-1969, when it became the Rehabilitation Gazette - a periodical with significantly less technologically oriented, reader-generated content. See also Jacqueline Foertsch, “Heads, You Win': Newsletters and Magazines of the Polio Nation," Disability Studies Quarterly 27, no. 3 (Summer 2007), http://www.dsq-sds.org/article/view/30/30.

10. "Happy Birthday"; "Masthead."

11. The periodical was begun as Paraplegia News in January 1951; from 1952-1953 it went by The Journal of Paraplegia, and returned to the Paraplegia News in 1954.

12. Collections and analyses of polio survivors' oral histories include Daniel J. Wilson, Living with Polio: The Epidemic and Its Survivors (Chicago: University of Chicago Press, 2005); Edmund Sass, George Gottfried, and Anthony Sorem, eds., Polio's Legacy: An Oral History (Lanham, Maryland: University Press of America, 1996) and selections from the Independent Living Movement Oral History project of the Regional Oral History Office, Bancroft Library, University of California at Berkeley.

13. Veterans of World War II received unprecedented support through the 1944 GI Bill, including advanced prosthetic technologies, long-term rehabilitation treatment, and subsidies for automobile and housing costs. Information for Soldiers Going Back to Civilian Life, War Department Pamphlet No. 21-24 (War Department, 1944); Wilma T. Donohue and Clark Tibbits, eds., The Disabled Veteran, vol. 239, The Annals of the American Academy of Political and Social Science (Philadelphia: The American Academy of Political and Social Science, 1945); for further discussion of disabled veterans' vs. civilians' benefits, see Audra Jennings, "With Minds Fixed On the Horrors of War: Liberalism and Disability Activism, 1940-1960" (Ph.D. diss., Ohio State University, 2008).

14. Jane Smith, Patenting the Sun: Polio and the Salk Vaccine (New York: Anchor Books, 1990); David M. Oshinsky, Polio: An American Story (New York: Oxford University Press, 2005); Wilson, Living With Polio. Polio was special among other disabilities, starting with medical care. The National Foundation for Infantile Paralysis provided significant funding for polio treatment, creating, at some hospitals, a sharp divide between the polio wards and spaces for other people with disabilities. At Rancho Los Amigos, Los Angeles County's rehabilitation hospital, the NFIP funded a separate polio treatment campus with, according to counselors, better food, better facilities, and better care. Lisa Livote, "Interview Notes for Roy Snelson," February 11, 1988, Papers of the Rancho Los Amigos Hospital, California Social Welfare Archives, University of Southern California.

15. Oshinsky, Polio: An American Story; Wilson, Living With Polio; on rehabilitation generally, see Edward N. Brandt and Andrew MacPherson Pope, eds., Enabling America: Assessing the Role of Rehabilitation Science and Engineering (Washington, DC: National Academy Press, 1997), 1-30; Glenn Gritzer and Arnold Arluke, The Making of Rehabilitation Medicine: A Political Economy of Medical Specialization, 1890-1980 (Berkeley and Los Angeles: University of California Press, 1985); Beth Linker, War's Waste: Rehabilitation in World War I America (Chicago: University of Chicago Press, 2011). 
16. Joe Macrander, "Hospital-Based Group Business Projects," Toomey J Gazette, 1968, 47; "Halt and Blind, Unbeatable Team," Toomey J Gazette, 1968, 77.

17. Henri-Jacques Stiker, A History of Disability (Ann Arbor: University of Michigan Press, 1999), especially 122-148.

18. Wilson, Living With Polio, 154; Diane and Bob Smith, "We Are Practically Independent. . .," Toomey J. Gazette, 1968, 32-33; Brinkman, "The Home and I."

19. Rusk, New Hope for the Handicapped, 95; Berns et al., Spinal Cord Injury, 9-13; Wilson, Living With Polio, 114-115, 154-155; Daniel J. Wilson, "And They Shall Walk: Ideal Versus Reality in Polio Rehabilitation in the United States," Asclepio, Revista De La Medicina y De La Cinecia 61 (July 2009): 175-192.

20. Wilson, Living With Polio, 134.

21. Cleo Living Aids (Cleveland, Ohio: Cleo Living Aids, 1981); Gary Karp, Choosing a Wheelchair: A Guide for Optimal Independence (Cambridge, MA: O'Reilly, 1998), 3-4; Belinda Bean and Susan Schapiro, "Consumer Warranty Law: Your Rights and How To Enforce Them" (Disability Rights Center, August 1977), 4-8; Deborah Kaplan Papers, Bancroft Library, University of California, Berkeley.

22. Susan O’Hara, “1958-1988,” 1988, Disability Rights and Independent Living Collection, Bancroft Library, University of California, Berkeley; Wilson, Living With Polio, 115; Cass Irvin, Home Bound: Growing up with a Disability in America (Philadelphia: Temple University Press, 2004), 34; many patients, uncomfortable with their braces, reverted to wheelchair use once they got home: Berns et al., Spinal Cord Injury, 10-11.

23. Wilson, Living With Polio, 154.

24. Irvin, Home Bound, 43.

25. Mary Grimley Mason, Life Prints: A Memoir of Healing and Discovery (New York: Feminist Press at the City University of New York, 2000), 23.

26. Distribution and Use of Hearing Aids, Wheel Chairs, Braces, and Artificial Limbs, July 1958-June 1959, Health Statistics from the U.S. National Health Survey (Washington, DC: U.S. Department of Health, Education, and Welfare, 1961); Brandt and Pope, Enabling America, 2-3; “Disability Status: 2000 — Census 2000 Brief”, n.d., http://www.census.gov/hhes/www/disability/ disabstat2k/table1.html.

27. Lilly Bruck, Access: The Guide to a Better Life for Disabled Americans, 1st ed. (New York: David Obst Books, 1978), 144; R.J. Feeney, "Are Aids for the Disabled Consumer Goods?" in The Use of Technology in the Care of the Elderly and the Disabled: Tools for Living, ed. Jean Bray and Sheila Wright (Westport, CT: Greenwood Press, 1980), 28-259.

28. Bruck, Access, 147. n.d.).

29. Colson Ball-Bearing Rubber-Tired Steel Wheels (Cleveland: The Colson-Cleveland Co.,

30. Edward W. Lowman and Howard A. Rusk, Self-Help Devices, Part 1 (New York: Institute of Physical Medicine and Rehabilitation, New York University Medical Center, 1962); Baruch Committee on Physical Medicine, "Community Rehabilitation Service and Center," Chart, 1945, Rusk Institute of Rehabilitation Medicine Archive, Archives and Special Collections, Ehrman Medical Library, New York University Medical Center Library; Muriel Zimmerman, "Accent on Progress," IPMR: A Chronicle of Independence, Fall 1955.

31. Howard A. Rusk and Eugene J. Taylor, Living with a Disability (Garden City, NY: Blakiston Co, 1953), 19-20.

32. Katherine Ott, "The Sum of Its Parts: An Introduction to Modern Histories of Prosthetics," in Artificial Parts, Practical Lives: Modern Histories of Prosthetics, ed. Katherine Ott, David Serlin, and Stephen Mihm (New York: New York University Press, 2002), 29.

33. Rusk, New Hope for the Handicapped, 80-81; Wilson, Living With Polio, 137. For further discussion of domestic environments installed inside rehabilitation hospitals, a tactic that dated to the 1920s, see Amy L. Fairchild, "Leprosy, Domesticity, and Patient Protest: The Social Context of a Patients' Rights Movement in Mid-Century America," Journal of Social History 39, no. 4 (Summer 2006): 1011-1043.

34. Charles L. Mee, A Nearly Normal Life: A Memoir (Boston: Little, Brown and Co., 1999),

35. Selwyn D. Collins, "The Incidence of Poliomyelitis and Its Crippling Effects, as Recorded in Family Surveys," Public Health Reports (1896-1970) 61, no. 10 (March 8, 1946): 327-355; Robert E. Serfling and Ida L. Sherman, "Poliomyelitis Distribution in the United States," Public Health Reports (1896-1970) 68, no. 5 (May 1953): 453-466; Barry Trevelyan, Matthew Smallman-Raynor, and Andrew D. Cliff, "The Spatial Dynamics of Poliomyelitis in the United States: From Epidemic Emergence to Vaccine-Induced Retreat, 1910-1971," Annals of the Association of American Geographers 95, no. 2 (June 2005): 269-293.

36. Most returned to the same house. The U.S. Census recorded 81 percent of Americans living in the same residence in 1960 as they did in 1950. U.S. Bureau of the Census, Statistical Abstract of the United States, 81st ed. (Washington, DC: U.S. Government Printing Office, 1960), 37. 
37. Carolyn Goldstein, Do It Yourself: Home Improvement in 20th-Century America (New York and Washington, DC: Princeton Architectural Press and The National Building Museum, 1998); Penny Sparke, As Long As It's Pink: The Sexual Politics of Taste (London: Pandora, 1995), 164-221.

38. Steven M. Gelber, "Do-It-Yourself: Constructing, Repairing and Maintaining Domestic Masculinity," American Quarterly 49, no. 1 (1997): 66-112.

39. Clifford Edward Clark, The American Family Home, 1800-1960 (Chapel Hill: University of North Carolina Press, 1986).

40. “\$9,990 Levitt Houses Boasts 70’ Lots,” Architectural Forum, October 1951, 217-219;

Polly Dunger, telephone conversation with author, July 19, 2009.

41. Betty Garee, Ideas for Making Your Home Accessible (Bloomington, IL.: Accent Special Publications, 1979), 5.

42. "Brainstorms," Toomey J Gazette, Fall-Winter 1959, 15-16. 1968,60

43. "Wheelchairs: Accessories, New Models, Oddments and Endments," Toomey J. Gazette,

44. "Equipment," Toomey J Gazette, Spring-Summer 1962, 42; John B. Wall, "Gadgets for the Physically Handicapped," Journal of Paraplegia, October 1952, 5-6; "Now! Roll Your Wheelchair Through Narrow Doors!," Valor, May 1953, 12.

45. "Equipment," Toomey J Gazette, Spring 1961, 11.

46. Zona Roberts, "Counselor for UC Berkeley's Physically Disabled Students' Program, Mother of Ed Roberts," Oral History conducted in 1994-1995 by Susan O'Hara (Regional Oral History Office, The Bancroft Library, University of California, Berkeley, 2000), 63-65.

47. Author conversation with Zona Roberts, Berkeley, CA, July 27, 2009.

48. "Homemaking," Toomey J Gazette, 1968, 16-27.

49. Ibid., 18.

50. Ibid., 21.

51. Ibid., 17.

52. Ibid., 19.

53. Roland Marchand, Advertising the American Dream: Making Way for Modernity, 19201940 (Berkeley: University of California Press, 1985), 144-146.

54. "Heloise Bowles Cruse-The Original Heloise," Heloise, n.d., http://www.heloise.com/ original heloise.html.

55. Heloise Cruse, "Hints from Heloise," The Evening Independent, March 21, 1970, sec. B, 4; Heloise Cruse, "Hints from Heloise," The Evening Independent, March 28, 1969, sec. B, 2.

56. Heloise Cruse, "Hints from Heloise," Ludington Daily News, July 17, 1971, 3; Cruse, "Hints from Heloise," Virgin Islands Daily News, May 30, 1974, 10.

57. "Mouthsticks," Toomey J Gazette, Spring 1960, 8-9.

58. "Editorial," Toomey J Gazette, Fall-Winter 1959; "TJG Presents First International Exhibition of Paralyzed Artists-Featuring Mouthstick Painting," Toomey J Gazette, Spring 1960, 19.

59. Jeffrey L. Meikle, American Plastic: A Cultural History (New Brunswick, NJ: Rutgers University Press, 1995), 83-96; Robert Friedel, "Scarcity and Promise: Materials and American Domestic Culture During World War II," in World War II and the American Dream, ed. Donald Albrecht and Margaret Crawford (Washington, DC: National Building Museum, 1995), 42-89.

60. Percy, Disability, Civil Rights, and Public Policy, 47-52.

61. Wilson, Living With Polio, 137.

62. Phil Draper, "It's Accessible, It's Electric, It's Fascinating," in Going Where You Wheel on Telegraph Avenue: An Evaluation of Accessibility on the Avenue Using a Model Applicable Anywhere, ed. Michael Daniels (Berkeley: The Center for Independent Living, 1984), 21.

63. O’Hara, "1958-1988"; Edward V. Roberts, "The UC Berkeley Years: First Student Resident at Cowell Hospital, 1962," in University of California's Cowell Hospital Residence Program for Physically Disabled Students, 1962-1975: Catalyst for Berkeley's Independent Living Movement, Oral History Conducted in 1994 by Susan O'Hara (Regional Oral History Office, The Bancroft Library, University of California, Berkeley, 2000), 16.

64. Brinkman, "The Home and I," 15; "Wheelchairs: Accessories, New Models, Oddments and Endments," 60.

65. Vince La Michle, "The Home and I,” Toomey J Gazette, Fall-Winter 1959, 17.

66. Shirley Teresa Wayda and Helen Shuemaker, eds. Material Culture in America: Understanding Everyday Life (Santa Barbara, Calif.: ABC-CLIO, 2008), 54.; James J. Flink, The Automobile Age (Cambridge, MA.: The MIT Press, 1988); David A Hounshell, From the American System to Mass Production, 1800-1932: The Development of Manufacturing Technology in the United States (Baltimore: Johns Hopkins University Press, 1984).

67. "Quad Drivers," Toomey J Gazette, Spring 1965, 38-41.

68. "Special Driving Control Created for President Roosevelt," Polio Chronicle 3, no. 7 (February 1934): unpaginated; Jum Benjaminson, "The Plymouth Cars of Franklin D. Roosevelt (and Eleanor)," AllPar.com (n.d.), http://www.allpar.com/history/roosevelt.html.

69. "Home, Franklin: The President and Other Polios Become Their Own Chauffeurs," Polio Chronicle, October 1933, unpaginated. 
70. Flink, The Automobile Age, 215.

71. Rep. Edith Nourse Rogers, Authorizing the Payment by the Administrator of Veterans'Affairs of the Purchase Price of Automobiles or Other Conveyances Purchased by Certain Disabled Veterans: Report (Washington, DC: 80th Congress, 1st Session, June 2, 1947), U.S. Congressional Serial Set.

72. Joe Jordan, "Hand Controlled,” Paraplegia News, January 1951, 7.

73. Flink, The Automobile Age, 215.

74. "Equipment: A Fourteen Page Feature on Quad Driving, Wheelchairs, Remote Controls, Idea Parade," Toomey J Gazette, 1968, 54.

75. "Quad Drivers," 38-41.

76. Brinkman, "The Home and I," 15.

77. "Travel by Respos," Toomey J Gazette, Spring 1961, 18-19.

78. You Too Can Drive! (Wixom, MI: Gresham Driving Aids, n.d.); Driving Aids and Accessories (Winimac, IN.: Braun Corporation, n.d.); Society of Automotive Engineers, Vehicle Controls for Disabled Veterans (Detroit: S.A.E. War Engineering Board, 1945), 14.

79. J. Sinko, "Steering Wheel Spinner," U.S. Patent 2,790,330, filed April 30, 1957; P.F. White, "Steering Wheel Spinner," U.S. Patent 2,561,961, filed November 23, 1948; J.E. Wood, "Steering Wheel Spinner," U.S. Patent 2,567,901, filed September 11, 1951. My thanks to Roger White of the National Museum of American History for discussion of steering wheel knobs and references.

80. Roger B. White, Home on the Road: The Motor Home in America (Washington, DC. Smithsonian Institution Press, 2000), 96.

81. Ronald Kline and Trevor Pinch, "Users as Agents of Technological Change: The Social Construction of the Automobile in the Rural United States," Technology and Culture 37, no. 4 (October 1, 1996): 763-795; Ron Eglash, “Appropriating Technology: An Introduction," in Appropriating Technology: Vernacular Science and Social Power (Minneapolis: University of Minnesota Press, 2004), vii-xx.

82. Wilson, Living With Polio, 154-155; Paul K. Longmore, Why I Burned My Book and Other Essays on Disability (Philadelphia: Temple University Press, 2003), 233.

83. "Editorial," 1.

84. Mary Lou Breslin, "Cofounder and Director of the Disability Rights Education and Defense Fund, Movement Strategist," in Disability Rights and Independent Living Movement Oral History Project, an oral history conducted in 1996-1998 by Susan O'Hara (Regional Oral History Office, The Bancroft Library, University of California, Berkeley, 2006), 44-45. 


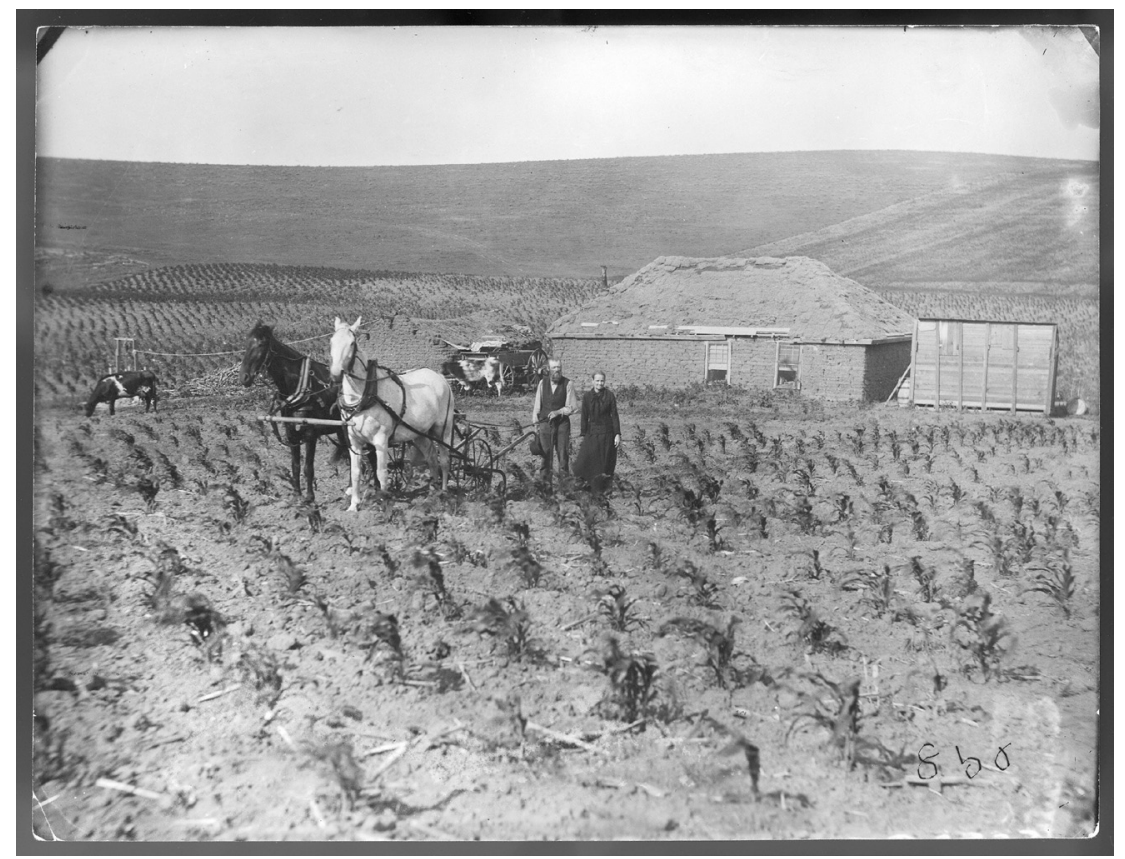

Figure 1: Using all the farm for crops - planting corn up to the front door." Photograph taken in 1888 in Custer County, Nebraska, the same year as Herman Melville published "John Marr," his devastating account of the demise of the prairies in Illinois as a result of monoculture farming. From the Samuel D. Butcher Collection, Nebraska State Historical Society [RG2608.PH2023]. Thanks to Kate Meyer, Spencer Museum of Art, University of Kansas. 